\title{
Modelling tools to evaluate China's future energy system - a review of the Chinese perspective
}

Mischke, Peggy

Publication date:

2014

Link back to DTU Orbit

\section{Citation $(A P A)$ :}

Mischke, P. (Author). (2014). Modelling tools to evaluate China's future energy system - a review of the Chinese perspective. Sound/Visual production (digital)

\section{General rights}

Copyright and moral rights for the publications made accessible in the public portal are retained by the authors and/or other copyright owners and it is a condition of accessing publications that users recognise and abide by the legal requirements associated with these rights.

- Users may download and print one copy of any publication from the public portal for the purpose of private study or research.

- You may not further distribute the material or use it for any profit-making activity or commercial gain

- You may freely distribute the URL identifying the publication in the public portal

If you believe that this document breaches copyright please contact us providing details, and we will remove access to the work immediately and investigate your claim. 


\section{Modelling tools to evaluate China's future energy system - a review of the Chinese perspective}

I nternational Energy Workshop 2014

Beijing, P.R. China

June 5, 2014

Peggy Mischke

Technical University of Denmark

Energy System Analysis

peym@dtu.dk
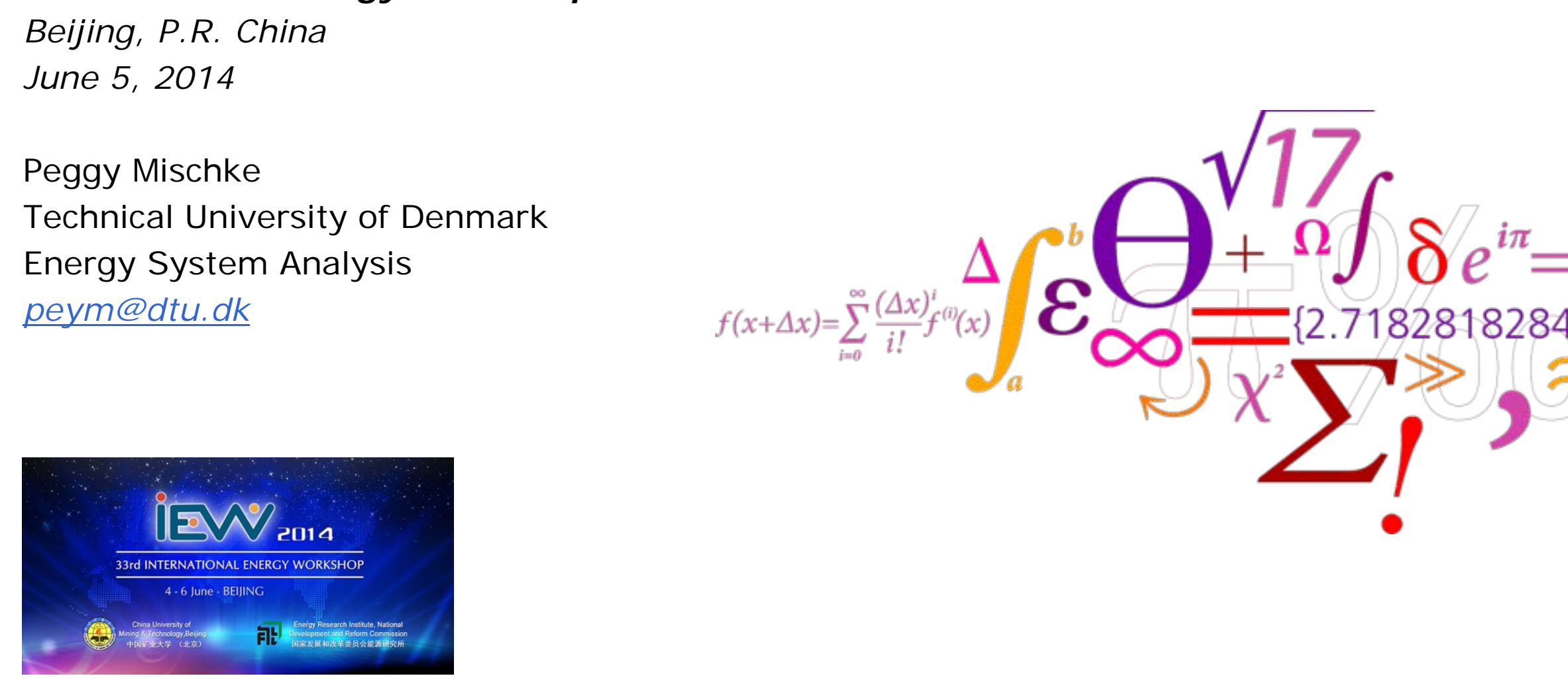


\section{Motivation and relevance}

- Research efforts of Chinese institutions to analyse China's future energy system increased tremendously over the past decade. One prominent research area is China's first binding $\mathrm{CO}_{2}$ emission intensity target per unit of GDP (Gross Domestic Product) and its impact on the country's economy and energy system.

- Robust, transparent and credible modelling tools to analyse China's future economy and energy system will play a key role in informing decision makers about a range of energy and climate policy impacts.

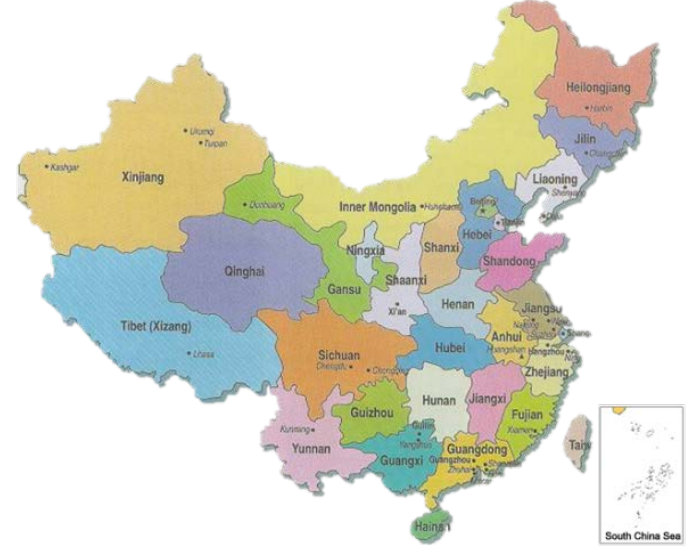

- This literature review of Chinese energy modelling tools aims to discuss and compare modelling tools, research questions, scenario results and policy recommendations of high priority from a Chinese perspective. 


\section{Methodology}

Establish a database of Chinese energy modelling tools

- academic journals and project based research reports

- English language

- publication period 2005 to 2013

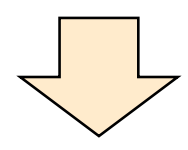

Review and classify the identified modelling tools by:

- underlying model structure

- research focus

- key result indicators of scenario studies

Summarize key policy recommendations

- to complement the quantitative results with qualitative policy recommendations 


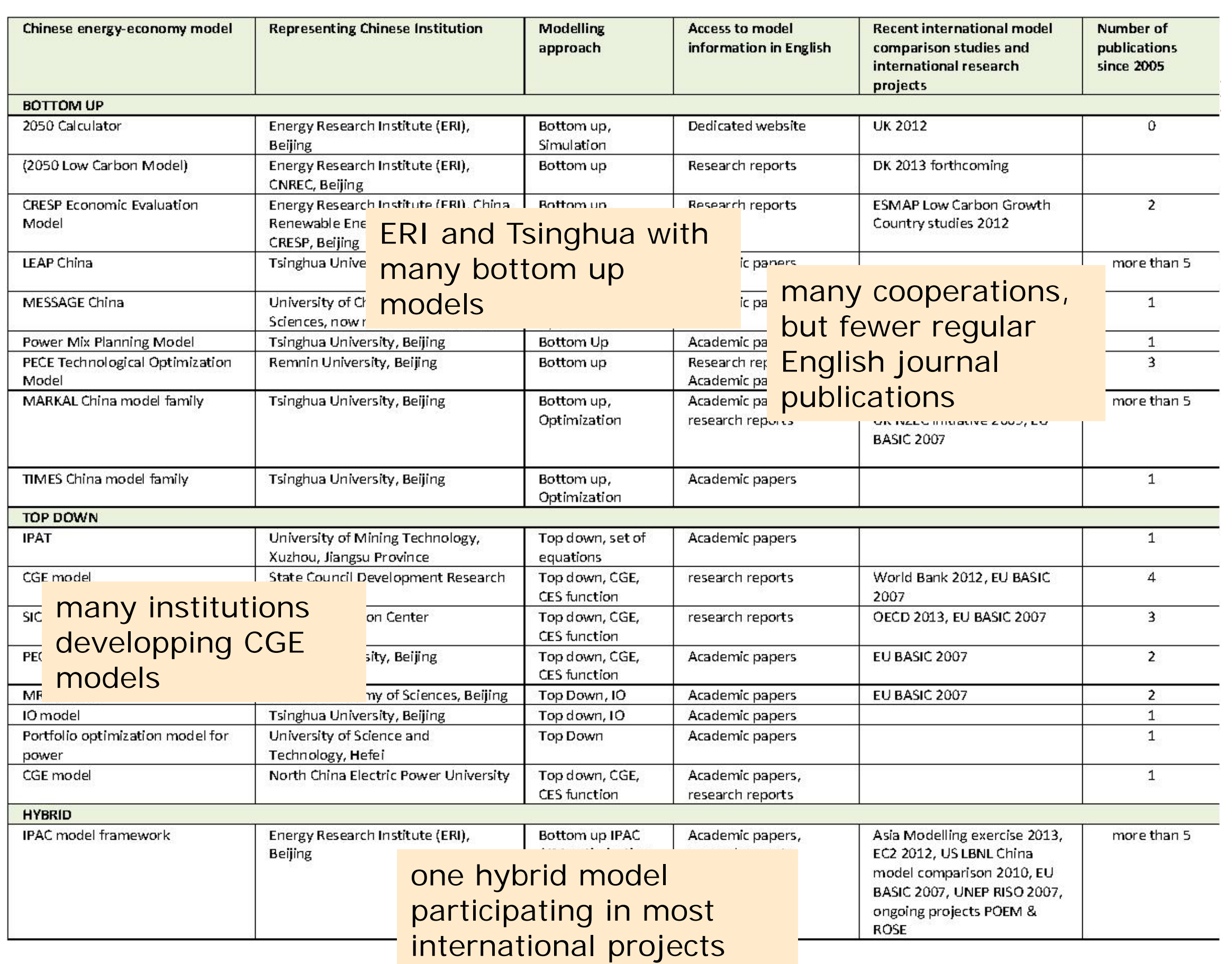




\section{Limitations: Access to information}

- The publication of modelling results in peer reviewed journals is mainly driven by the different Chinese universities. Only 13 of the 18 reviewed modelling tools are however discussed in peer-reviewed journal papers.

- For some of the modelling tools reviewed, the number of international available publications since 2005 was moreover limited. All of the modelling tools developed by a Chinese university published at least once in a peer reviewed scientific journal in English since 2005.

- Non-university institutions of the Chinese state publish results from energy modelling studies almost exclusively in project reports, related policy briefs and magazines.

- Multiple Chinese modelling tools are rarely compared in one study, such as done in the Asia Modelling Exercise in 2013. 


\section{The study included 18 Chinese modelling tools from 10 Chinese institutions}

Overview of modelling tools and institutions.

\begin{tabular}{|c|c|c|}
\hline Acronym & Modelling tool & Institution \\
\hline 2050-Calc-ERI & China 2050 calculator & Energy Research Institute \\
\hline CGE-NCEPU & Computable general equilibrium model & North China Electric Power University \\
\hline CREAM-ERI & China renewable energy analyses model & Energy Research Institute \\
\hline DCGE-SIC & Dynamic computable general equilibrium model & State Information Centre \\
\hline EEM-ERI & Economic evaluation model & Energy Research Institute \\
\hline IO-TU & Input output model & Tsinghua University \\
\hline IPAC-ERI & Integrated policy assessment model for China & Energy Research Institute \\
\hline IPAT-CUMT & IPAT model & China University of Mining and Technology \\
\hline LEAP-TU & Long-range energy alternatives planning model & Tsinghua University \\
\hline MARKAL-TU & Market allocation model & Tsinghua University \\
\hline MESSAGE-UCAS & $\begin{array}{l}\text { Model for energy supply strategy altematives and } \\
\text { their general environmental impact }\end{array}$ & University of the Chinese Academy of Sciences \\
\hline MRIO-CAS & Multi-regional input output model & Chinese Academy of Sciences \\
\hline MSCGE-DRC & Multi-sector computable general equilibrium model & Development Research Centre, State Council \\
\hline PMP-TU & Power mix planning model & Tsinghua University \\
\hline POM-USTC & Portfolio optimization model & University of Science and Technology of China \\
\hline TEDCGE-RU & Technology oriented dynamic computable general equilibrium model & Renmin University of China \\
\hline TIMES-TU & The integrated MARKAL-EFOM system & Tsinghua University \\
\hline TOM-RU & Technological optimization model & Renmin University of China \\
\hline
\end{tabular}

- Beijing based institutions are currently the drivers of energy model development in China. 


\section{Results: Classification of modelling tools}

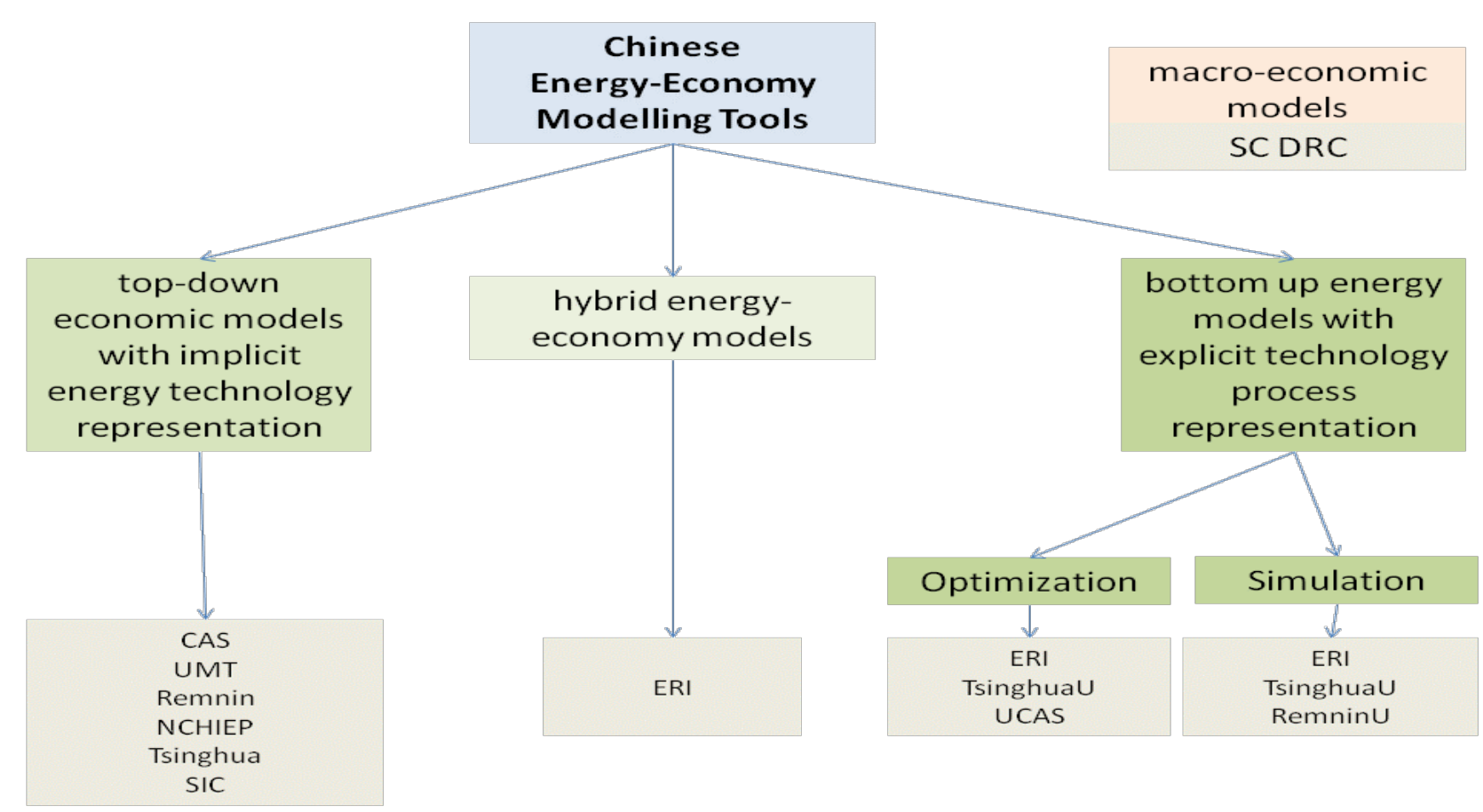

- From the 18 reviewed modelling tools: 8 bottom-up models and 8 top-down models, among these 2 simulation models; 3 optimization models; 4 CGE models and 2 IO models were described.

- A hybrid modelling framework was less frequently described. 


\section{Results: Comparing GDP growth projections across models}
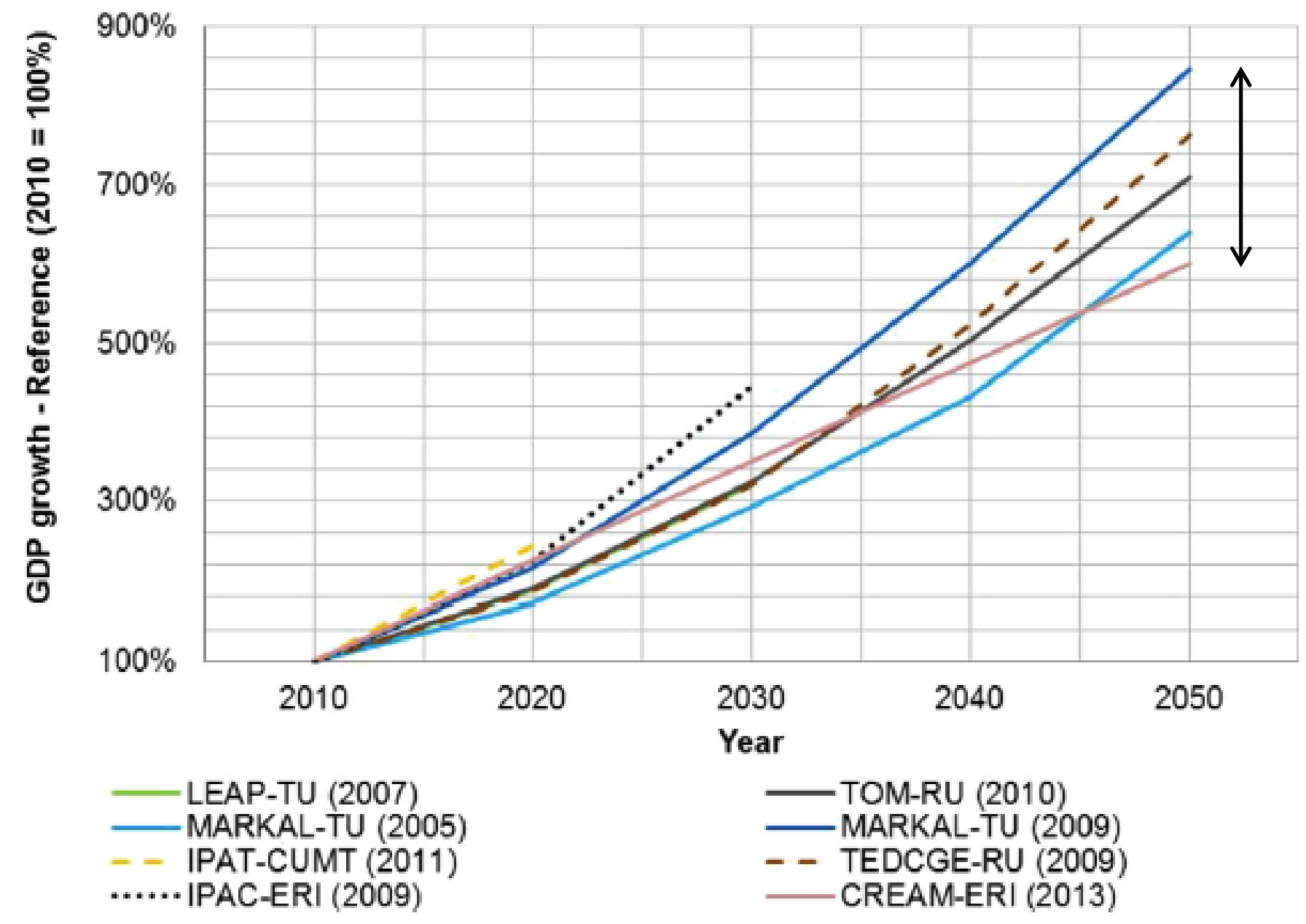

Fig. 1. Comparison of China's future GDP growth across models - reference scenarios. 


\section{Results: Comparing energy demand and $\mathrm{CO}_{2}$ emission growth accross reference scenarios}

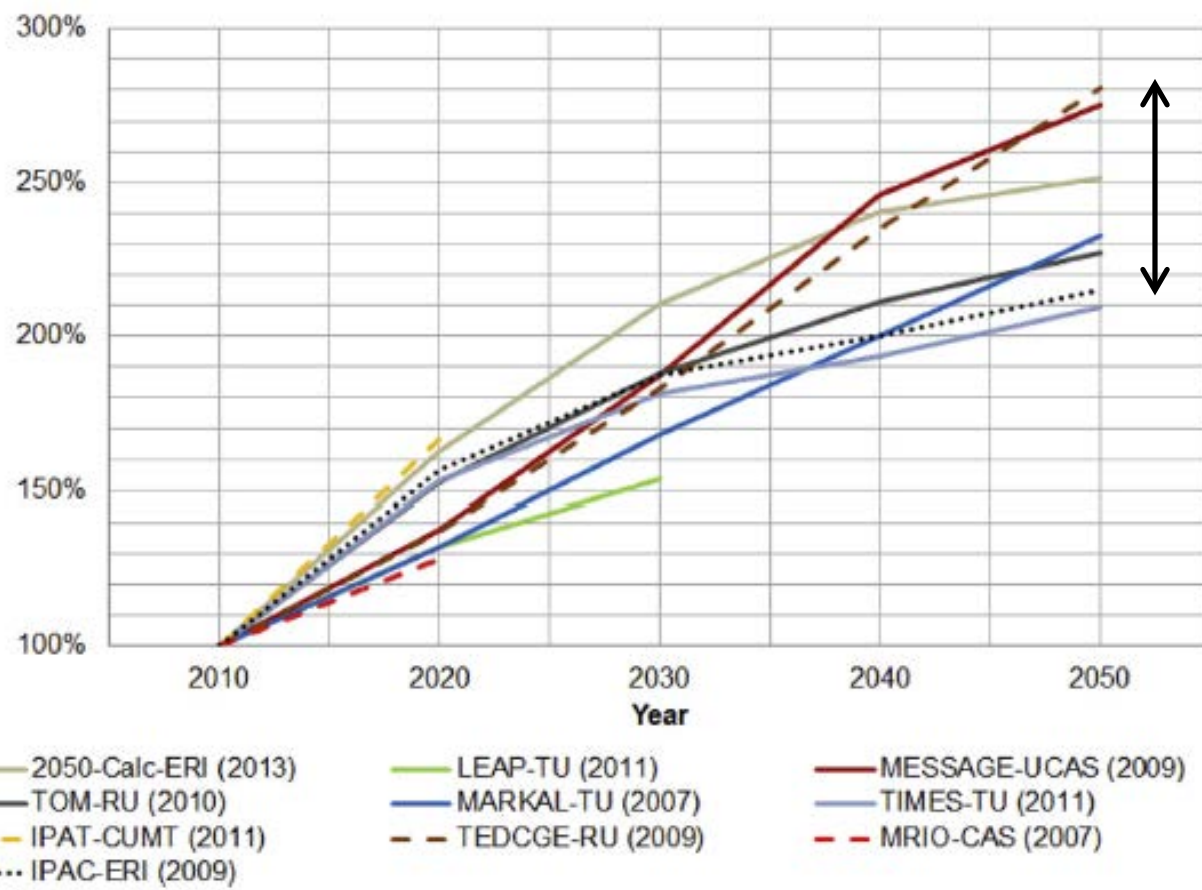

Fig. 2. Comparison of China's future energy demand across modelling tools - reference scenarios.

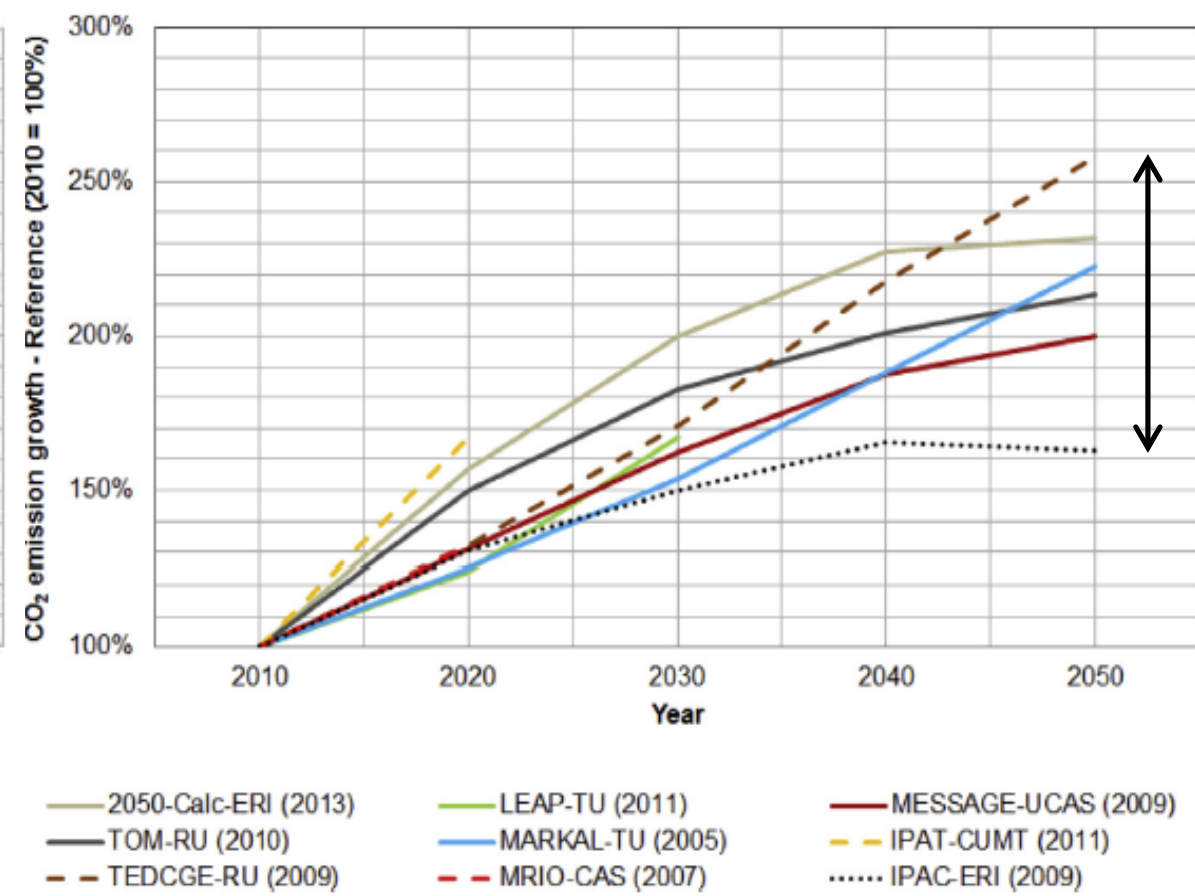

Fig. 3. Comparison of China's future $\mathrm{CO}_{2}$ emissions across modelling tools - reference scenarios. 


\section{Results: Main application areas}

Comparison of main application areas - policy scenarios.

\begin{tabular}{|c|c|c|c|c|c|c|c|}
\hline Modelling tool - acronym & $\begin{array}{l}\text { Economic and } \\
\text { system costs }\end{array}$ & $\begin{array}{l}\text { Economic } \\
\text { Re-structuring }\end{array}$ & $\begin{array}{l}\text { Labour } \\
\text { adjustments }\end{array}$ & $\begin{array}{l}\text { Impact on } \\
\text { energy demand }\end{array}$ & $\begin{array}{l}\text { Comparison of multiple } \\
\text { end use sectors }\end{array}$ & $\begin{array}{l}\text { Power system } \\
\text { transition }\end{array}$ & $\begin{array}{l}\text { Emissions, natural } \\
\text { resources and environment }\end{array}$ \\
\hline 2050-Calc-ERI & & & & $\sqrt{ }$ & $\sqrt{ }$ & & $\sqrt{ }$ \\
\hline CGE-NCEPU & $\sqrt{ }$ & $\sqrt{ }$ & & $\sqrt{ }$ & & $\sqrt{ }$ & \\
\hline CREAM-ERI & $\sqrt{ }$ & $\sqrt{ }$ & & $\sqrt{ }$ & $\sqrt{ }$ & $\sqrt{ }$ & $\sqrt{ }$ \\
\hline DCGE-SIC & $\sqrt{ }$ & $\sqrt{ }$ & $\sqrt{ }$ & & & & $\sqrt{ }$ \\
\hline EEM-ERI & $\sqrt{ }$ & & & & & $\sqrt{ }$ & \\
\hline IO-TU & $\sqrt{ }$ & & $\sqrt{ }$ & & & & \\
\hline IPAC-ERI & $\sqrt{ }$ & $\sqrt{ }$ & & $\sqrt{ }$ & $\sqrt{ }$ & $\sqrt{ }$ & $\sqrt{ }$ \\
\hline IPAT-CUMT & $\sqrt{ }$ & & & $\sqrt{ }$ & & & $\sqrt{ }$ \\
\hline LEAP-TU & $\sqrt{ }$ & & & $\sqrt{ }$ & $\sqrt{ }$ & $\sqrt{ }$ & $\sqrt{ }$ \\
\hline MARKAL-TU & $\sqrt{ }$ & & & $\sqrt{ }$ & $\sqrt{ }$ & $\sqrt{ }$ & $\sqrt{ }$ \\
\hline MESSAGE-UCAS & $\sqrt{ }$ & & & & $\sqrt{ }$ & $\sqrt{ }$ & $\sqrt{ }$ \\
\hline MRIO-CAS & & & & $\sqrt{ }$ & & & $\sqrt{ }$ \\
\hline MSCGE-DRC & $\sqrt{ }$ & $\sqrt{ }$ & & & & & \\
\hline PMP-TU & & & & $\sqrt{ }$ & & $\sqrt{ }$ & \\
\hline POM-USTC & $\sqrt{ }$ & & & & & $\sqrt{ }$ & \\
\hline TEDCGE-RU & $\sqrt{ }$ & & & & & & $\sqrt{ }$ \\
\hline TIMES-TU & $\sqrt{ }$ & & & $\sqrt{ }$ & $\sqrt{ }$ & $\sqrt{ }$ & $\sqrt{ }$ \\
\hline TOM-RU & $\sqrt{ }$ & & & & & $\sqrt{ }$ & $\sqrt{ }$ \\
\hline
\end{tabular}




\section{Results: energy - economy links}

A continuous rapid growth is possible for China with the right policy mix, including economic adjustment towards less industry and more services in a mid- and long-term perspective.
Carbon pricing has a strong negative impact on China's energy intensive sectors $\rightarrow$ large decline of coal mining, petroleum industry and power generation sectors
There are important net losses for China's coal industry under a renewable electricity generation target of $15 \%$ by 2020 .
There are high costs when introducing low carbon technologies at a larger scale in China.
Investments in low-carbon technologies in the short-term should be avoided until further research is carried out.

Emission reduction policies will reduce future economic growth in China.
The earlier an emission constraint is implemented in China, the higher the GDP loss.
There will be high social welfare loss and GDP loss under various carbon constraints in China. 


\section{Results: technology choices}

Fossil power will dominate in China until 2050, even after the introduction of carbon pricing.

Coal will remain the major future energy carrier in China.

Mandatory renewable energy targets will challenge resource limits and regional energy disparities inside China, but will decrease air pollution.

Under ambitious renewable energy targets, the renewable energy share in primary energy demand could increase from $9 \%$ in 2010 to $56 \%$ in 2050.
Nuclear and hydropower as well as demand management will play an increasing role when introducing emission reduction policies in the electricity sector.
CCS technologies will be more promising to reduce China's $\mathrm{CO}_{2}$ emissions until 2050 than wind and nuclear energy.

Power technology diversifications away from coal decreases China's portfolio risk, but increases generation costs.

Any future mitigation of the country's $\mathrm{CO}_{2}$ emissions will mainly come from cleaner coal combustion and CCS. 


\section{Results: future emissions}

The period before 2020 is very crucial to determine the future direction and level of energy demand, supply and emissions in China. There is a need to transform economic development patterns timely to control rapid growth of final energy demand.

Recent and continued technological progress will make it possible for China to limit its $\mathrm{CO}_{2}$ emissions and for these emissions to peak before 2025 .
An absolute emission reduction pledge of China under the Kyoto protocol should be avoided.
A potential emission stabilization period between 2035 and 2050 is suggested for China, after a period of growing energy demand from industry, transport, buildings and consumers.

Emissions from the iron and steel industry are a key future challenge for China.
Resource availability and environmental pressures will present mid- and longterm constraints to China's economic growth. 


\section{Key conclusions}

- Chinese researchers showed a strong research focus on cost-related impacts of energy and climate policies - independent from the underlying modelling approach and the institution

- Economic growth in line with the official government targets is a main factor driving future energy demand and $\mathrm{CO}_{2}$ emission increase across models.

- Many models suggested a cleaner and more efficient use of coal, partly combined with an increase in nuclear power generation. Only a few modelling studies pointed out to benefits of increased use of renewable energies in China.

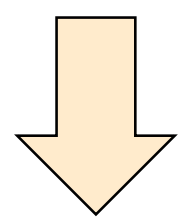

The Chinese perspective, independently from the modelling approach and institution, suggests a rather gradual and long-term transition towards a low carbon economy in China.

An improved standardisation with regards to model descriptions and results presentations is suggested for future research in this area. 


\section{Further information}

\section{Email:peym@dtu.dk}

China energy blog: www. peggymischke.com

These results are published in ENERGY. DOI: 10.1016/j.energy.2014.03.019

The publication includes an extensive appendix with a description of each reviewed model.

Energy 69 (2014) 132-143

\begin{tabular}{ccc|}
\hline & Contents lists available at ScienceDirect & Energy \\
\hline ELSEVIER & journal homepage: www.elsevier.com/locate/energy & \\
\hline
\end{tabular}

Review

Modelling tools to evaluate China's future energy system - A review of the Chinese perspective

(1) CrossMark

Peggy Mischke*, Kenneth B. Karlsson

Department of Management Engineering, Energy Systems Analysis Division, Technical University of Denmark, Denmark

\section{Sino - Danish Center for Education and Research}

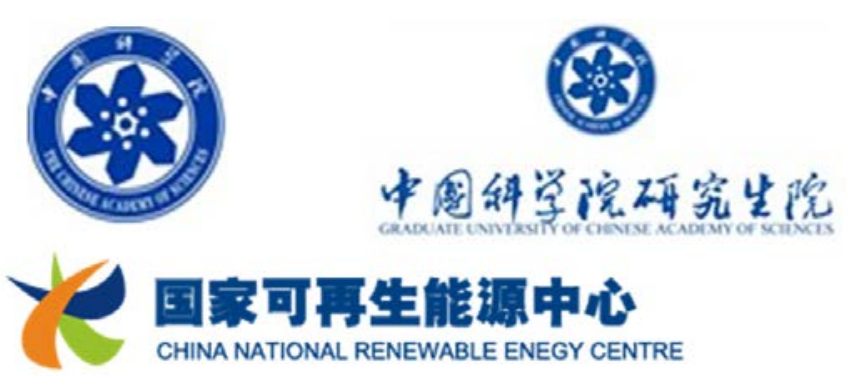

